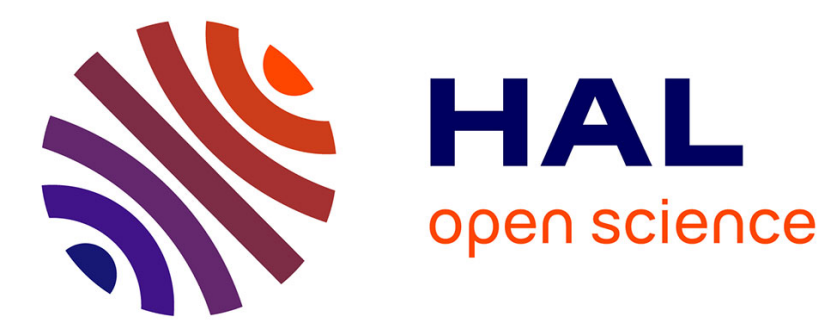

\title{
Under Attack: Terrorism and International Trade in France, 2014-16
}

\author{
Volker Nitsch, Isabelle Rabaud
}

\section{To cite this version:}

Volker Nitsch, Isabelle Rabaud. Under Attack: Terrorism and International Trade in France, 2014-16. 2019. hal-02411649

\author{
HAL Id: hal-02411649 \\ https://hal.science/hal-02411649
}

Preprint submitted on 15 Dec 2019

HAL is a multi-disciplinary open access archive for the deposit and dissemination of scientific research documents, whether they are published or not. The documents may come from teaching and research institutions in France or abroad, or from public or private research centers.
L'archive ouverte pluridisciplinaire HAL, est destinée au dépôt et à la diffusion de documents scientifiques de niveau recherche, publiés ou non, émanant des établissements d'enseignement et de recherche français ou étrangers, des laboratoires publics ou privés. 
Document de Recherche du Laboratoire d'Économie d'Orléans

Working Paper Series, Economic Research Department of the University of Orléans (LEO), France

DR LEO 2019-12

Under Attack:

Terrorism and International Trade in France, 2014-16

Volker NITSCH

Isabelle RABAUD

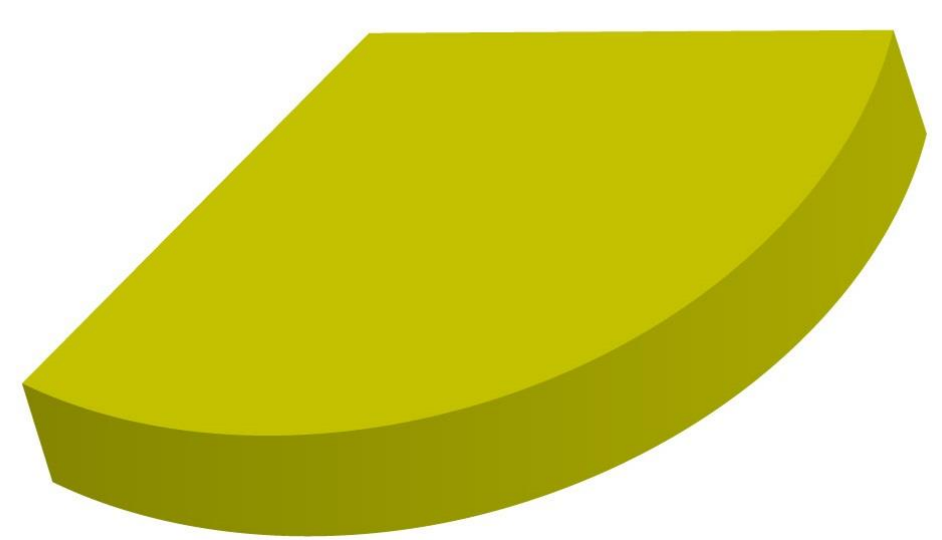

Mise en ligne / Online : 05/12/2019 
November 24, 2019

\title{
Under Attack: \\ Terrorism and International Trade in France, 2014-16*
}

\author{
Volker Nitsch \\ Technische Universität Darmstadt
}

\author{
Isabelle Rabaud \\ Univ. Orléans, CNRS, LEO
}

\begin{abstract}
$\underline{\text { Abstract }}$
Terrorist events typically vary along many dimensions, making it difficult to identify their economic effects. This paper analyzes the impact of terrorism on international trade by examining a series of three large-scale terrorist incidents in France over the period from January 2015 to July 2016. Using firm-level data at monthly frequency, we document an immediate and lasting decline in cross-border trade after a mass terrorist attack. The reduction in trade mainly takes place along the intensive margin, with particularly strong effects for partner countries with low border barriers to France, for firms with less frequent trade activities and for homogeneous products. A possible explanation for these patterns is an increase in trade costs due to stricter security measures.
\end{abstract}

JEL Classification Codes: F14; F52

Keywords: shock; insecurity; uncertainty

* We thank Stefan Goldbach, Jérôme Héricourt, Laura Hering, Christophe Hurlin, Laura Lebastard, Daniel Mirza, Patrick Villieu and participants at presentations in Bern (European Trade Study Group), Darmstadt and Orléans (Association Française de Science Economique) for helpful comments. Rabaud gratefully acknowledges financial support from the project "Behaviour of Economic Agents, Utility and Security (in times of) Terror BEcAUSeTerror", funded by the French National Research Agency (grant number ANR-18CE39-0006). The trade data used in this paper has been graciously provided by the Direction Générale des Douanes et Droits Indirects (douanes françaises).

Contacts:

Volker Nitsch

Technische Universität Darmstadt, Hochschulstr. 1, 64289 Darmstadt, Germany

Tel.: +49-6151-16 57261; E-mail: nitsch@vwl.tu-darmstadt.de

Web: http://www.vwl2.wi.tu-darmstadt.de

Isabelle Rabaud

Univ.Orléans, CNRS, LEO, FRE 2014

Laboratoire d'Économie d'Orléans, Faculté Droit Economie Gestion, Rue de Blois BP 26739, 45067 Orléans Cedex 2, France

Tel.: +33-238492518; E-mail: isabelle.rabaud@univ-orleans.fr

Web: http://www.leo-univ-orleans.fr/fr/membres/\#isabelle.rabaud@univ-orleans.fr 


\section{Introduction}

Terrorist activity, aiming to destabilize a society, often has measurable economic consequences. Occasionally, terrorists target a country's economy directly, attacking, for instance, critical infrastructure or a specific sector of relevance. More importantly, however, terrorism also induces sizable indirect costs. As terrorist incidents lead to greater risk and uncertainty, they distort economic decisions. Likewise, future behavior is changed by measures taken in response to terrorism (such as actions by authorities that seek to reinforce security). ${ }^{1}$

In view of these wide and diverse repercussions, a growing literature aims to analyze the economic impacts of terrorism. ${ }^{2}$ Empirical studies range from an examination of firmlevel effects at short frequencies to an assessment of long-term macroeconomic consequences. While there is considerable variation in identification strategies, most of this research is characterized by a strong (positive) correlation in the level of economic detail that is analyzed and the frequency of the data that is used--a feature which is already observable in Abadie and Gardeazabal's (2003) seminal study of the terrorist conflict in the Basque region of Spain. In order to examine the evolution of the Basque economy under terrorism, they effectively conduct two separate empirical exercises, first performing a synthetic control analysis with annual data of per capita GDP over the period from 1955 to 2000, and then providing an event study to analyze the daily returns of the stocks of firms at the time of the 1998-1999 truce.

In this paper, we deviate from this pattern. In particular, we use highly disaggregated data to examine the impact of terrorist incidents on an aggregate measure of economic activity, a country's international trade, over short periods of time. As a result, we are able to provide evidence on both the direct and immediate economic costs of terrorism. ${ }^{3}$ Moreover, by looking at a series of three large-scale terrorist incidents which hit France in 2015 and 2016, our analysis avoids some of the problems which are typically faced in the literature. Case studies, for instance, suffer from limited generalizability as terrorist incidents often vary along many dimensions, including the public's awareness of the terrorist threat and subsequent government responses. For studies analyzing multiple episodes, in contrast, a

\footnotetext{
${ }^{1}$ Draca, Machin, and Witt (2011), for instance, find that the increase in police presence following the July 2005 terrorist bombings in central London sizably reduced criminal activity.

${ }^{2}$ Gaibulloev and Sandler (2019), among others, provide an extensive review of this literature.

${ }^{3}$ This approach is fundamentally different from the analysis of the response of market prices, especially on stock markets, which mainly capture expected effects.
} 
frequent challenge is how to quantify the intensity of hard-to-compare terrorist incidents. Moreover, when analyzing the impact of terrorism on trade, an important issue is whether terrorists damaged trade infrastructure, thereby erecting a (temporary) physical barrier to trade. $^{4,5}$

In view of these ambiguities, it is not surprising that existing studies, based on less detailed data, report a variety of findings on the effects of terrorism on trade, dependent on the research design. Early contributions, such as Nitsch and Schumacher (2004) and Blomberg and Hess (2006), analyze annual panel data sets of aggregate bilateral trade flows and find that terrorism has a statistically significant and robust negative effect on trade, similar to other types of conflict (see, for instance, Martin, Mayer, and Thoenig, 2008). ${ }^{6}$ Other studies explore more disaggregated data and report less conclusive results. Egger and Gassebner (2015), for instance, examine country-level trade data at monthly frequency. According to their estimates, terrorist incidents have no measurable effect on trade during the first year of their occurrence. Bandyopadhyay, Sandler, and Younas (2018) highlight another potential data aggregation issue, with possible variation in the terrorism-trade elasticity at the product level. Analyzing trade in primary commodities and manufactured goods separately, their results suggest that the terrorism-induced reduction in total trade is solely due to a decline in trade of manufactured goods, while trade in primary commodities may even increase after a terrorist attack. Despite these attempts to provide more detailed insights, however, none of the studies examines the type of micro data that we use in our analysis, which allows us to address various issues in the empirical analysis of the effects of terrorism on trade simultaneously, from the joint examination of multiple terrorist events to a dissection of the effect along several dimensions (including variation across countries, firms, and products as well as over time).

Our work is also related to studies on sudden disruptions in France's external trade. Michaels and Zhi (2010), for instance, examine the impact of the deterioration of relations

\footnotetext{
${ }^{4}$ Infrastructures make an appealing target for terrorists. As the United Nations (2018, p. 20) notes: "Interfering in the functioning of a CI [critical infrastructure], ideally with the possibility of generating cascading effects, allows terrorists to maximized damage in just one shot and instill fear to levels that would not be attainable as easily by attacking "ordinary" targets."

${ }^{5}$ In our study, we examine evidence from a single country, France, but we pool across events in an arguably fairly homogeneous setting, thereby generating results which go beyond the findings from case studies.

${ }^{6}$ De Sousa, Mirza, and Verdier (2018) expand the analysis to capture general equilibrium effects, also finding a reduction in trade for countries located in proximity to terror, even when they do not source it.
} 
between the United States and France in 2002 and 2003 when the French government opposed US efforts to obtain a United Nations (UN) Security Council mandate to use military force against Iraq. Analyzing annual UN Comtrade data at the 4-digit product level, they find that the worsening attitudes reduced bilateral trade by about 9 percent. In similar fashion, Pandya and Venkatesan (2016) show that during the 2003 dispute over Iraq the market share of French-sounding brands in US supermarkets declined, with the strongest decline exactly in the week with the most anti-France Fox News mentions.

The remainder of the paper is organized as follows. Section 2 briefly reviews the recent increase in terrorist activity in France. In Section 3, we describe our empirical approach and our data. The heart of our paper is Section 4 which presents the results of our empirical analyses. Finally, Section 5 concludes.

\section{Terrorism in France}

France, like many other Western European countries, has been a frequent target of terrorist attacks. According to the "Global Terrorism Database", a widely-used compilation of terrorist incidents around the world, more than 2,600 events have been recorded in France since 1970, with a median number of 39 entries per year. ${ }^{7}$ With the rise of Islamist extremism, however, the number and especially the violence of attacks increased sizably. ${ }^{8}$ The new dimension of terrorist activity in France is illustrated by the French Minister of the Interior Brice Hortefeux who declared in October 2010, in response to these developments, that "the terrorism threat is real, we have increased our vigilance". 9 Temporarily, the security threat level was increased to scarlet (the highest). ${ }^{10}$ Still, despite these (counter-)measures, France witnessed a number of terrorist incidents in the following years, including three large-scale terrorist attacks. Table 1 provides a list of terrorist incidents in France over the period from 2014 to 2016.

\subsection{Major Terrorist Incidents}

In January 2015, the wider Paris region (Île-de-France) was subject to several related terrorist attacks. On January 7, two gunmen forced their way into the offices of the satirical

\footnotetext{
${ }^{7}$ For a detailed description, see https://www.start.umd.edu/gtd/.

${ }^{8}$ Klausen (2017) provides a discussion of the background of the surge of jihadism in France.

${ }^{9}$ See https://www.interieur.gouv.fr/Archives/Archives-ministre-de-1-Interieur/Archives-deBrice-Hortefeux-2009-2011/Questions-d-actualite/05-10-2010-Reponse-QAG-terrorisme. ${ }^{10}$ See https://www.publicsenat.fr/lcp/politique/sarkozy-d-clenche-plan-vigipirate-carlatemidi-pyr-n-es-230306.
} 
weekly newspaper "Charlie Hebdo" and killed 12 people, injuring 11 others. After the attack, a large nationwide manhunt followed, with more than 88,000 police and military forces deployed, during which the attackers took hostages before they were killed two days later. ${ }^{11}$ Simultaneously, another gunman who was reportedly in contact with the attackers killed a traffic policewoman in a shooting on January 8, and killed four people in a hostage taking of a kosher supermarket on January 9 before being killed by police.

The violence of the attacks, the shooting of journalists, and the high level of organization and configuration in networks of operational terrorist cells provoked strong reactions in France and beyond. On Sunday, January 11, about two million people, including the political leaders of more than 40 countries, gathered in Paris for a unity march against terrorism.

Another wave of coordinated attacks took place eleven months later, in November 2015. On the evening of November 13, three groups of terrorists launched six distinct attacks, including suicide bombings near the country's national sports stadium in Saint-Denis, mass shootings at restaurants and bars in Paris, and a massacre in the Bataclan music theater. With a death toll of 130, these attacks have been the deadliest attacks in Europe in a decade (European Police Office, 2016). Moreover, while the attackers killed themselves as soon as capture seemed imminent, the search for additional suspects and accomplices continued for weeks.

A third major terrorist attack occurred in July 2016. On Bastille Day, France's national holiday, which is celebrated every year on July 14, a terrorist drove a truck along the pavement of the "Promenade des Anglais" in Nice, ploughing into a crowd of some 30,000 people who gathered to watch the fireworks display that had just ended. The attack killed 86 people and left hundreds of people physically and psychologically wounded.

\section{$\underline{2.2 \text { Government Responses }}$}

In response to the attacks, actions were taken along various dimensions, from symbolic to constitutional, mainly to combat terrorism. Immediately after the January 2015 attacks, the French government decreed, for the fifth time only since 1945, a national day of mourning ${ }^{12}$ and declared that France was now officially "at war with terrorism". ${ }^{13}$ A few

\footnotetext{
${ }^{11}$ See https://www.interieur.gouv.fr/Archives/Archives-ministre-de-1-Interieur/ArchivesBernard-Cazeneuve-avril-2014-decembre-2016/Interventions-du-ministre/Declaration-de-M.Bernard-Cazeneuve-a-la-presse-le-jeudi-8-janvier-2014.

${ }^{12}$ See Le Figaro July 17, 2016; online available at http://www.lefigaro.fr/actualitefrance/2016/07/17/01016-20160717ARTFIG00108-le-deuil-national-une-decision-rare-en-
} 
months later, in June 2015, the parliament adopted a new intelligence law, which, among other provisions, extended the number of objectives that can justify extrajudicial surveillance. $^{14}$

In reaction to the November 2015 attacks, for the second time since 1962, France adopted a set of derogatory measures through the "state of emergency", a judicial framework which gives exceptional powers to state authorities. ${ }^{15}$ Under this emergency rule, days and nights raids and home confinements of terrorist suspects were allowed; the army was deployed in the public space; meetings in public places were forbidden ${ }^{16}$; and, most notably for our purposes, border controls were reestablished. ${ }^{17}$ Initially declared for a period of twelve days, the state of emergency was extended six times, during which some of the measures have been transposed into ordinary law. It officially expired, after almost two years, on November 1, 2017 when a new anti-terrorism law went in force. ${ }^{18}$

Since the state of emergency is designed as a prompt response to exceptional circumstances, temporarily limiting the exercise of certain civil freedoms, the government's new legal arsenal aims at preventing terrorist acts while preserving individual liberties. Despite being less restrictive, however, the new legislation contains measures which have the potential to (negatively) impact trade directly. These measures include, among others, an

france.php. National days of mourning were also declared after the November 2015 and July 2016 attacks.

${ }^{13}$ See https://www.gouvernement.fr/en/tribute-to-the-victims-of-the-attacks.

${ }^{14}$ The law was adopted with large majority, despite some public opposition. For more details, see https://www.gouvernement.fr/en/parliament-adopts-the-intelligence-bill.

${ }^{15} \mathrm{See}$ https://www.gouvernement.fr/en/state-of-emergency-in-metropolitan-france-what-arethe-consequences.

${ }^{16}$ Further illustrating the abrupt standstill of public life, all schools and universities were closed in the Ile de France (November 14-16), all school trips were cancelled in France and abroad (November 14-22), and street market concessionaries were closed in Paris until November 19.

${ }^{17}$ France is a member country of the Schengen area, within which any person may cross the internal borders without being subjected to border checks; see https://ec.europa.eu/homeaffairs/what-we-do/policies/borders-and-visas/schengen_en. In practice, it is not uncommon that member countries of the Schengen area temporarily suspend the freedom to cross internal borders without checks, especially in the context of foreseeable cases such as sport events or high-level summit meetings. France, however, continuously prolonged the reintroduction of border controls, which were originally established for a period of one month on November 13, 2015, mainly arguing that there is a persistent terrorist threat; see https://ec.europa.eu/homeaffairs/what-we-do/policies/borders-and-visas/schengen/reintroduction-border-control_en. ${ }^{18}$ For a detailed documentation, see https://www.vie-publique.fr/actualite/faq-citoyens/etaturgence-regime-exception/. 
extension of the scope and duration of border controls, allowing, for instance, checks to be carried out in wider geographical areas and for longer periods of time than before. ${ }^{19}$

\section{Methodology and Data}

\subsection{Methodology}

In our empirical analysis, we deviate substantially from previous work, which mainly uses large panel data sets, covering many years and countries, to identify the effect of terrorism in trade. Still, our baseline estimation approach is fairly standard. Following the literature, we apply a conventional gravity model, adapted to highly disaggregated data at short frequency, in which we dummy out for most standard determinants of trade. ${ }^{20}$ In particular, our benchmark econometric specification takes the form:

$$
\text { Trade }_{\mathrm{cfp}, \mathrm{t}}=\beta \mathrm{Attack}_{\mathrm{t}}+\gamma_{\mathrm{cfp}}+\delta_{\mathrm{m}}+\zeta_{\mathrm{y}}+\varepsilon_{\mathrm{cfp}, \mathrm{t}}
$$

where Trade $_{\text {cfp,t }}$ is a measure of international shipments to/from France at the country-firmproduct (cfp) level in month $\mathrm{t}$, Attack is an indicator variable that takes the value of one when a mass terrorist attack occurred in France in month $\mathrm{t}$ (and is zero otherwise), and we include a full set of country-firm-product-specific $\left(\gamma_{\mathrm{cfp}}\right)$, calendar month $\left(\delta_{\mathrm{m}}\right)$ and year-specific $\left(\zeta_{\mathrm{y}}\right)$ fixed effects. The coefficient of interest to us is $\beta$, the effect of mass terrorist attacks on trade, while the fixed effects hold constant for all time-invariant determinants of trade (such as distance and language) as well as seasonal and annual variation in trade. Moreover, for short sample periods, the dyadic country-firm-product fixed effects also effectively control influences on bilateral trade, which are, in principle, variable over time, but stable in the short term (such as the size of a foreign source or destination market). Consequently, we restrict our sample to 36 months, covering the period from January 2014 to December 2016.

In our estimations of equation (1), instead of looking at the effects of a single terrorist attack, we pool across the three large-scale terrorist incidents in France in January 2015,

\footnotetext{
${ }^{19}$ See https://www.gouvernement.fr/en/reinforcing-internal-security-and-the-fight-againstterrorism.

${ }^{20}$ In their review of various estimation methods of the gravity equation, Head and Mayer (2015) show that this estimator, which they label 'least squares with country dummies' (LSDV) technique, typically works well.
} 
November 2015 and July $2016 .{ }^{21}$ Although there are notable differences in the type of attack (and other features of the incident such as the number of casualties), all three events are classified as mass terrorist attacks. More importantly, each of these incidents has received massive public attention. Since terrorists aim to intimidate a large audience beyond that of the immediate victims (Enders and Sandler, 2012), publicity is of crucial importance to them, highlighting the critical role of the media in propagating the fear of terrorism. Krueger (2007, p. 132), for example, argues that "[b]ecause terrorist strikes themselves affect only a small proportion of the population, media coverage is essential if terrorism is to have widespread psychological, economic, and political effects. ${ }^{, 22}$ According to this metric, then, the attacks in our sample can be expected to exhibit effects of a different order of magnitude than other terrorist incidents. Figure 1 plots the monthly number of occurrences of the words "Terrorisme" or "Terroriste" in national and regional newspapers in France. Irrespective of the exact measure that is used, the figure clearly illustrates both the outstanding and comparable level of intensity in the media coverage of the three major attacks. In months of the attack, the word count of terrorism jumps by more than factor three. Moreover, the effect is remarkably short-lived. The spikes are strongly confined to the months of the attack.

\subsection{Data}

Our main source of data is the merchandise trade statistics of France, compiled by the General Direction of Customs and Indirect Duties (Direction Générale des Douanes et Droits Indirects). In the data set provided to us for research purposes ${ }^{23}$, trade activities are reported by country-firm-product triplet in monthly intervals. In particular, we observe, for any given month, the firm (identified by its SIREN number ${ }^{24}$ ), the type of trade activity (exports, imports), the (nominal) value and quantity shipped, the destination or source country and the

\footnotetext{
${ }^{21}$ Our analysis, therefore, goes beyond a plain case study, but falls short of analyzing all terrorist incidents in France. We also deviate from another popular approach in the empirical literature, which weights attacks by observable outcomes such as the number of casualties and/or fatalities.

${ }^{22}$ Krueger (2007, p. 135) even hypothesizes that terrorists may time their attacks to achieve a maximum impact in terms of news coverage. Examining the number of attacks by hour of the day, he finds a bimodal distribution, with most attacks occurring in the morning hours and in the evening.

${ }^{23}$ At this level of detail, data are covered by statistical confidentiality. Access can be provided, however, through the Comité du Secret Statistique; see https://www.comite-dusecret.fr.

${ }^{24}$ The SIREN number (Système d'Identification du Répertoire des Entreprises) is a nine-digit firm identifier maintained by the national statistics institute of France, INSEE; see https://www.insee.fr/en/metadonnees/definition/c2047.
} 
product code. Products are classified according to the 8-digit Combined Nomenclature (CN8), containing about 9,500 items, excluding war material. ${ }^{25}$ Our sample covers the period from January 2014 until December 2016.

Table 2 describes the raw data in detail. Following standard practice, our focus is on imports, which tends to be the generally more accurate data. As it turns out, the imports data set is also larger, along every dimension, including the number of firms, the number of products, and the value of trade. Few firms, however, import the same product from the same supplier country every month. At the most disaggregated (country-firm-product) level, therefore, the data set is strongly unbalanced. Still, the trade database is huge, containing more than 1 million import observations per month.

Figure 2 plots aggregate trade for France in monthly frequency. While there is a notable seasonal pattern, with a sharp drop in trade levels in August, it is reassuring to note that there is generally no trend in trade over our sample period; French exports and imports in 2016 are, on average, almost unchanged from 2014. Moreover, monthly aggregates derived from micro data are virtually identical to published trade figures from the national statistics institute of France, INSEE.

\section{Empirical Results}

\subsection{Benchmark Results}

Table 3 reports our baseline estimation results. Our unit of analysis is a country-firmproduct triplet with a positive entry in the trade statistics in a given month, yielding a sample of nearly 40 million observations for a period of 36 months. In column (1), we use, similar to conventional gravity models, the (log of the) value of imports as dependent variable. The estimate of $\beta$ is negative and, with a t-statistic in excess of 22 , statistically highly significant. Being hit by a major terrorist attack is associated with an immediate decline in imports. The effect is also economically large. The point estimate of -0.02 implies that in months of a mass terrorist attack French imports decrease, on average, by about $2 \%(\approx \exp (-0.02)-1)$. Since $\beta$ captures, however, the trade response in the same month of the attack, the magnitude of the estimated decrease in trade is dependent on the within-month timing of the attack, which makes a direct interpretation of the estimated coefficient difficult. ${ }^{26}$ Still, even without taking

\footnotetext{
${ }^{25}$ For a more detailed description, see https://lekiosque.finances.gouv.fr/site_fr/etudes/methode/elaboration.asp.

${ }^{26}$ In our sample, each attack occurred in the first half of the month.
} 
the precise estimate too literally, it seems clear that foreign trade falls measurably after an attack.

In the remaining columns of the table, we analyze the sensitivity of our baseline estimate to minor modifications of the regression set-up. First, we replace our regressand with other measures of bilateral import activity. In particular, we examine the weight, quantity and unit value of imports (instead of its total nominal value). For each of these measures, the finding of an immediate (negative) effect of terrorism on trade is robust, although somewhat smaller in magnitude.

In another perturbation, we include an additional year of data (2013). Enlarging the sample by adding trade observations for 12 months unaffected by mass terrorist incidents allows for a more precise identification of the (unreported) month-of-the-year fixed effects, which control for seasonal variation in imports. As shown, with this extension, which increases the number of observations to more than 50 million, our estimate of $\beta$ turns out to be, if anything, even larger. In the final column at the extreme right of Table 3, we use the nominal value of bilateral exports, instead of imports, as our dependent variable. While exports may be a less accurate measure of cross-border trade activity, we find, again, strong evidence of a prompt, economically and statistically significant decrease in trade after major terrorist attacks.

\subsection{Robustness}

We check the sensitivity of our results extensively. In a first robustness test, we modify the set of fixed effect controls, thereby making our regression specification of the gravity model even more demanding. Specifically, it could be argued that our combination of calendar month and year fixed effects is not sufficiently appropriate to account for all timevariant factors, which are not exactly specific to a particular month. Despite our short sample period, there could still be patterns in the data, such as, for instance, product-specific seasonal variation in trade. Therefore, to deal with this issue, we sequentially substitute the set of plain calendar month fixed effects with (substantially) larger sets of time-varying fixed effects.

The results in Table 4 show that the terrorism effect on trade is strongly robust to these modifications. For example, as shown in the first column of the table, the estimate of $\beta$ is basically unchanged when calendar month fixed effects are replaced by country-specific calendar month fixed effects (which increases the number of month-of-the-year fixed effect categories from 12 to 2,740). Moreover, this finding holds up for other combinations of country-, firm- or product-specific calendar month fixed effects, as tabulated in the middle 
columns of Table 4. Pushing things to the extreme, we include, in the last column of the table, a set of fixed effects which accounts for monthly variation at the country-firm-product level. This regression includes, along with year fixed effects (3 categories) and time-invariant (dyadic) country-firm-product fixed effects $(2,436,939$ categories), more than 10 million fixed effect controls. ${ }^{27}$ However, even with this extension, the estimated $\beta$ coefficient remains largely unchanged, thereby providing strong support for our baseline specification which uses fixed effects more parsimoniously.

Another potential problem of our analysis is that our sample does not include observations of zero trade. Consequently, our estimates may be biased. ${ }^{28}$

Unfortunately, we are computationally unable to generate a balanced panel, including zeros, at the most disaggregate (country-firm-product) level of information. Therefore, we gradually aggregate our data along various dimensions and rerun our analysis for balanced panels. ${ }^{29}$ Table 5 presents the results of these exercises. At the country-product level, for instance, our sample comprises, with this extension, more than 84 million observations; when we add data for 2013 (in the final column of Table 5), sample size even increases to 112 million observations. At more aggregate levels, in contrast, the number of observations declines quickly, despite balancing. For total imports by country, for instance, our sample comprises (247 source territories $\times 36$ months=) 8,892 observations. Reviewing the results, the effect increases in magnitude, but there is less precision in the estimate, as sample size falls. Overall, however, our key finding turns out to be again remarkably robust.

Table 6 reports estimation results for alternative estimation techniques. In our baseline estimation, we assess the significance of $\beta$ based on Huber-White heteroscedasticityconsistent standard errors. In the first three columns of the table, we now consider standard errors clustered at the country, firm, and product level, respectively, without much effect.

We also apply a Poisson pseudo-maximum likelihood (PPML) estimator, which has become a common procedure in the gravity literature. ${ }^{30}$ In column (4), we present the results for our baseline specification, analyzing country-firm-product triplets; in the column at the extreme right of the table, we tabulate the analogue for a balanced panel (including zeros) at the (more aggregated) country-product level. Again, our finding of an immediate measurable decline in trade after a terrorist attack remains virtually unchanged.

\footnotetext{
${ }^{27}$ Also, due to singleton observations, sample size falls considerably.

${ }^{28}$ See, for instance, Helpman, Melitz, and Rubinstein (2008).

${ }^{29}$ Following conventional practice, we replace observations of missing trade with zero and consistently add a small amount (of 0.01) to the value of imports before taking logs.

${ }^{30}$ See, for instance, Santos Silva and Tenreyro (2006).
} 


\subsection{Trade Pattern over Time}

Next, we explore the trade pattern in response to the attacks over time in more detail. Obviously, any (event study) analysis is limited by the short time window between the attacks. Since the second attack followed nine months after the first attack, and the third attack followed seven months after the second attack, there is not much degree of freedom when overlaps in the classification of months as before or after the attack are to be avoided.

In a first extension, then, we gradually expand our regression specification in equation (1) to additionally include indicator variables for months before and after the attacks. Similar to our benchmark specification, the estimated coefficients capture any systematic deviation in trade, but now for periods other than the month of the attack, holding other things constant. In particular, we estimate equations of the form:

$$
\operatorname{Trade}_{\mathrm{cfp}, \mathrm{t}}=\Sigma_{\mathrm{k}} \beta_{\mathrm{k}} \operatorname{Attack}_{\mathrm{t}+\mathrm{k}}+\gamma_{\mathrm{cfp}}+\delta_{\mathrm{m}}+\zeta_{\mathrm{y}}+\varepsilon_{\mathrm{cfp}, \mathrm{t}}
$$

In Table 7, estimation results are reported for a specification which allows to identify trade effects for the period from one month before the attacks to six months after the attacks. ${ }^{31}$ Similar to Table 3, we tabulate coefficient estimates for different regressands and sample periods. Figure 3 provides an accompanying graph for the value of imports when the period after the attacks is gradually extended, illustrating, for instance, that the exact choice of $\mathrm{k}$ has no sizable effect on the results. A clear pattern seems to be observable. Reassuringly, there is no substantial deviation in trade from its average in the month before the attack. After the sharp drop in trade in the month of the attack, documented in the baseline estimates, there is a correction in the following month when trade temporarily bounces back to normal. Over the next few months, however, trade remains disproportionately low before the effect gradually fades out roughly six months after the attacks. Overall, our estimates indicate that mass terrorist attacks have not only an immediate, same-month impact on trade, but that there may be lasting negative consequences for cross-border economic activities.

To further analyze the duration of the effect of terrorism on trade, we modify, once again, our regression specification. As in equation (2), we analyze an indicator variable, Attack, which takes a value of one also for months other than the month of the attack. However, instead of allowing for separate $\beta$ 's, we now estimate a single coefficient such that

\footnotetext{
${ }^{31}$ That is, subscript $\mathrm{k}$ takes values from -1 to +6 , and we estimate eight coefficients, which describe the pattern of trade immediately before and in the six months after the attacks.
} 
$\beta$ captures the average aggregate effect of the attacks on trade over a specified window of time. Consequently, our estimation equation takes the form:

$$
\operatorname{Trade}_{\mathrm{cfp}, \mathrm{t}}=\Sigma_{\mathrm{k}} \beta \text { Attack }_{\mathrm{t}+\mathrm{k}}+\gamma_{\mathrm{cfp}}+\delta_{\mathrm{m}}+\zeta_{\mathrm{y}}+\varepsilon_{\mathrm{cfp}, \mathrm{t}}
$$

Figure 4 plots the results from this regression exercise when the time period of interest $(\mathrm{t}+\mathrm{k})$ is gradually extended. Dots denote the point estimate of $\beta$ for the period given on the $\mathrm{x}-$ axis, with each estimate being derived from a different regression; the vertical lines illustrate the 95 percent confidence interval around these estimates. As before, results are reported for a period of up to six months after the attacks $(t+6)$ to avoid overlaps.

The estimation results mimic those of Figure 3. The strongest decline in trade is observed immediately in the month in which the terrorist attack occurs. While this effect is sizably reduced (by about one half) when the next month is additionally taken into consideration, the negative effect is partly reinforced again after this correction. For the period covering the first six months after the attack, the average (aggregate) reduction in trade is still economically sizable, with a magnitude which is about half as large as the immediate decline in trade in the month of the attack, and statistically significant at any reasonable confidence level. Therefore, in line with our previous finding, the negative effect of mass terrorist attacks turns out to be remarkably persistent.

\subsection{Decompositions}

Another extension aims to identify factors behind the response in cross-border trade to terrorist attacks. In particular, we decompose aggregate trade along extensive and intensive margins and analyze the effects of terrorism for each margin separately. Specifically, following Bernard, Jensen, Redding, and Schott (2009), we decompose, separately for imports and exports, the total value of foreign trade of France in a given month into the unique number of partner countries, the unique number of firms reporting trade activities, the unique number of products shipped, the average value of trade per country-firm-product triplet as well as the density of trade (i.e., the fraction of all possible country-firm-product combinations for which trade is positive). We then examine how the margins of trade respond to the shock of a mass terrorist attack.

Table 8 presents the results. In this table, each cell represents a different regression, with the regressand tabulated at the left, over the sample tabulated at the top. Because of the 
small size of the sample, with one observation per month, we also report results for the extended sample period from 2013 to 2016.

Although we are generally cautious in interpreting the results due to the small number of observations, even at this very aggregate level, terrorist attacks have a sizable negative impact on the value of trade, although the estimated coefficients often just miss statistical significance at the 95 percent confidence level. Taken at face value, the point estimates of about -0.045 imply that imports and exports of France are lower by about 4 percent in months of mass terrorist attacks, after controlling for calendar month and year fixed effects, a drop in trade which is twice as large as our benchmark estimate suggests. In total, 19 of the 24 estimated coefficients take a negative sign. However, while many of those estimates are insignificantly different from zero at conventional levels, the most consistent and strongest effects are obtained for the intensive margin, which is, in our setting, defined as the average value of trade per country-firm-product triplet. The coefficients on this variable are not only economically large, accounting for about two thirds of the estimated decline in the total value of trade, but also of at least borderline statistical significance. Overall, our results suggest that the variation in trade is mainly driven by the intensive margin, similar to Bernard, Jensen, Redding, and Schott's findings (2009) for the response in trade during the 1997 Asian financial crisis.

In another decomposition exercise, we replicate our pooled analysis for the three terrorist incidents separately. While we consider the joint analysis of several attacks a particular strength of our study, it may also be interesting to review estimation results by individual attack. Figure 5 plots the estimated $\beta$ coefficients. As shown, the estimated trade effects vary considerably, both across incidents and over time. For the first attack (January 2015), the decline in trade is relatively stable and persistent over time. Ten months later, in contrast, at the time of the second attack (November 2015), trade is sizably above the benchmark and only becomes negative over the following months. Yet another pattern is observed for the third attack (July 2016), when trade falls sharply in the month of the attack and gradually normalizes afterwards. While there may be numerous reasons for these divergent findings, including the sequencing of the attacks, possible anticipation effects and various types of government responses, the results, in our view, strongly reinforce our argument in favor of a pooled empirical analysis.

\section{$\underline{4.5 \text { Mechanisms }}$}


In this section, we explore the potential mechanisms via which terrorism might affect trade. In principle, terrorist events could translate into a range of economic consequences. However, for cross-border trade, three channels are perhaps of particular importance. ${ }^{32}$ First, terrorist attacks could cause real physical damage which has the potential to especially harm trade when terrorists target, for instance, a country's infrastructure (such as a port or a pipeline) or key industry (such as, for instance, oil and gas). Second, terrorist acts usually create fear and uncertainty which can lead to a change in behavior of economic agents, including the extent of their interactions with the outside world. Third, terrorist attacks often prompt governmental countermeasures which could make cross-border transactions more difficult or expensive. Although we cannot definitively distinguish across the different mechanisms or rule out the possibility that there are other intermediating variables at work, we empirically identify country, firm and product characteristics which affect the strength of the trade response to terrorism and, therefore, possibly support any of these mechanisms. Our focus is particularly on the latter two channels, since the mass terrorist incidents in our sample did not cause much trade-related physical destruction.

To examine the heterogeneity in the estimated trade effects across different subgroups of our data, we run regressions of the form in equation (1) but now add interaction terms between binary subgroup identifiers and the Attack dummy. Moreover, findings of variation in immediate effects are complemented with results from a similar analysis for a longer time horizon of six months, based on an augmented version of equation (3).

We begin our analysis by reviewing various country features. In particular, it could be argued that a behavioral shift away from international exchange in response to the attacks should have affected trade with all foreign countries alike; consequently, the estimated coefficients on the interaction terms should be indistinguishable from zero, irrespective of the group that is chosen. In contrast, increased security measures, such as the (re-)introduction of administrative border barriers after the terrorist attacks, can be expected to have particularly reduced trade with countries with previously no or low existing border barriers with France.

Table 9 presents the results. The left panel of the table reports the coefficient estimates for the response in trade in the month of the attack; the right panel tabulates the corresponding average effects for the six-month period after the attacks. Interestingly, for shipments from French overseas territories to the mainland of France, we do not find any measurable difference from the pattern in international trade. The estimated coefficient on the interaction term is even negative for months with major terrorist incidents, but turns positive when the

\footnotetext{
${ }^{32}$ See, for instance, Nitsch and Schumacher (2004) for a more detailed discussion.
} 
post-attack period analyzed is expanded. Still, none of these effects is significantly different from zero. Next, we examine various (partly overlapping) groups of countries for which France faces largely no restrictions in cross-border exchange: countries with a common land border with Metropolitan France; other member countries of the Schengen area; and other member countries of the European Union. For each of these country groups, we observe a disproportionately large decline in trade after the attacks. In a joint analysis, however, the immediate effect is clearly dominated by the fall in trade with other member countries of the Schengen area, while the effect spreads geographically to member countries of the European Union in the six months following the attacks. Finally, there is evidence that the trade relationships with the home countries of attackers' parents (Algeria, Morocco, Tunisia, Mali) deteriorated sizably in the aftermath of the attacks, especially when longer periods are analyzed. Overall, our estimation results indicate that the negative effect of mass terrorist attacks on trade is partly a reflection of increased security measures which were imposed in response to these incidents.

Table 10 presents analogous results for various firm-level characteristics. In a first step, we differentiate firms by size. In particular, we identify firms which consistently declare international trade operations in every month of our sample period and classify these firms as 'large firms'. For companies with large distribution networks and frequent trade activities, both greater uncertainty and higher trade costs after terrorist attacks are expected to be less of a problem than for other firms. Indeed, in line with this intuition, our results show that the trade activities of established trading companies are substantially less affected by the terrorist attacks than those of other traders. The ability to cope with the trade shock becomes even more pronounced, perhaps not surprisingly, as the time window of analysis is expanded.

In addition, we hypothesize that the geographic location of a company may be relevant for the size of the trade effect. For instance, companies located in the immediate vicinity of the terrorist incidents may be particularly harmed by the attacks. Likewise, firms located in border regions may suddenly experience the difficulties of newly erected border barriers. Unfortunately, from the firm identifier in our trade data set, we are unable to differentiate between the headquarter location and the location of the production plant. However, when we identify the location of a firm by its headquarter, firms located in a département with a common land border with a neighboring country and firms located in a département affected by the attacks (Paris, Hauts-de-Seine, Seine-St-Denis, Val-de-Marne, Alpes Maritimes) both experience an additional (negative) effect on trade, especially over the longer term. In sum, the finding of geographic heterogeneity in the effect of terrorism on trade (that is, localized 
effects) provides support for the view that acts of terrorism have a direct impact on economic activity. Similarly, however, the finding is also in line with the hypothesis that stricter security measures and border checks inhibit trade.

Finally, we examine variation in the estimated impact of terrorism on trade across product level characteristics and report the results in Table 11. For example, it could be argued that product categories which are typically traded on public markets have been particularly strongly affected by the events, given that the mass terrorist incidents led to a sudden standstill in public life. We analyze this issue by classifying products of chapters 2-4, 6-9 and 16 in the Combined Nomenclature as 'fresh food' and adding a corresponding interaction term. The results in the first column of Table 11 indeed imply a massive decline in imports of such commodities. This effect, however, is only temporary and disappears completely within six months after the attack.

We also explore variation in trade according to the Rauch (1999) classification of goods. As before, we find that some product categories are more affected by the attacks than others. A particularly large and consistent decline in trade, however, is observed for products which are typically traded on organized exchanges. Since trade relationships are much easier to quit and (re-)establish for such homogeneous products, this finding indicates that terrorist activities increase trade costs.

\section{Conclusions}

Terrorist attacks take different forms and target different goals, making it difficult to identify their economic effects. In particular, studies examining the immediate economic impact of terrorist incidents are rare. They often rely on case studies or the analysis of stock market returns (which mainly reflect the expectations of market participants).

In this paper, we provide a novel analysis of the macroeconomic effect of terrorist attacks in the short run. In particular, we analyze the impact of terrorism on international trade by examining a series of three large-scale terrorist incidents in France over the period from January 2015 to July 2016. Using firm-level data at monthly frequency, we document an immediate and lasting decline in cross-border trade after a mass terrorist attack. In particular, we estimate that, in months of a mass terrorist attack, foreign trade of France decreases, on average, by about $2 \%$. Moreover, exploring the potential mechanisms via which terrorism might affect trade, we find that the reduction in trade mainly takes place along the intensive margin, with particularly strong effects for countries with low border barriers, for firms with less frequent trade activities and for homogeneous products. These patterns are broadly in line 
with an increase in trade costs due to stricter security measures imposed by the French government in response to the mass terrorist attacks. 


\section{References:}

Abadie, Alberto and Javier Gardeazabal. 2003. "The Economic Cost of Conflict: A Case Study of the Basque Country," American Economic Review. 93 (1): 113-132.

Bandyopadhyay, Subhayu, Todd Sandler, and Javed Younas. 2018. "Trade and Terrorism: A Disaggregated Approach,” Journal of Peace Research. 55 (September): 656-670.

Bernard, Andrew B., J. Bradford Jensen, Stephen J. Redding, and Peter K. Schott. 2009. “The Margins of US Trade," American Economic Review. 99 (May): 487-493.

Berrebi, Claude and Esteban F. Klor. 2010. "The Impact of Terrorism on the Defence Industry," Economica. 77 (July): 518-543.

Blomberg, S. Brock and Gregory D. Hess. 2006. "How Much Does Violence Tax Trade?," Review of Economics and Statistics. 88 (November): 599-612.

De Sousa, José, Daniel Mirza, and Thierry Verdier. 2018. "Terror Networks and Trade: Does the Neighbor Hurt?," European Economic Review. 107 (August): 27-56.

Draca, Mirko, Stephen Machin, and Robert Witt. 2011. "Panic on the Streets of London: Police, Crime, and the July 2005 Terror Attacks," American Economic Review. 101 (August): 2157-2181.

Egger, Peter and Martin Gassebner. 2015. "International Terrorism as a Trade Impediment?," Oxford Economic Papers. 67 (January): 42-62.

Enders, Walter and Todd Sandler. 2012. The Political Economy of Terrorism. Cambridge: Cambridge University Press.

European Police Office. 2016. European Union Terrorism Situation and Trend Report (TESAT) 2016. The Hague: European Police Office (Europol).

Gaibulloev, Khusrav and Todd Sandler. 2019. "What We Have Learned about Terrorism since 9/11,” Journal of Economic Literature. 57 (June): 275-328.

Head, Keith and Thierry Mayer. 2015. "Gravity Equations: Workhorse, Toolkit, and Cookbook," in Elhanan Helpman, Kenneth Rogoff and Gita Gopinath (editors) Handbook of International Economics vol. 4. Oxford: Elsevier, 131-195.

Helpman, Elhanan, Marc Melitz, and Yona Rubinstein. 2008. "Estimating Trade Flows: Trading Partners and Trading Volumes," Quarterly Journal of Economics. 123 (May): 441487.

Klausen, Jytte. 2017. “Terror in the Terroir: The Roots of France's Jihadist Problem,” Foreign Affairs. 96 (September/October): 166-172.

Krueger, Alan B. 2007. What Makes a Terrorist. Princeton: Princeton University Press.

Martin, Philippe, Thierry Mayer, and Mathias Thoenig. 2008. "Make Trade Not War?," Review of Economic Studies. 75 (July): 865-900. 
Michaels, Guy and Xiaojia Zhi. 2010. "Freedom Fries," American Economic Journal: Applied Economics. 2 (July): 256-81.

Nitsch, Volker and Dieter Schumacher. 2004. "Terrorism and International Trade: An Empirical Investigation,” European Journal of Political Economy. 20 (June): 423-433.

Pandya, Sonal S. and Rajkumar Venkatesan. 2016. "French Roast: Consumer Response to International Conflict - Evidence from Supermarket Scanner Data," Review of Economics and Statistics. 98 (March): 42-56.

Rauch, James E. 1999. "Networks versus Markets in International Trade," Journal of International Economics. 48 (June): 7-35.

Santos Silva, J.M.C. and Silvana Tenreyro. 2006. "The Log of Gravity,” Review of Economics and Statistics. 88 (November): 641-658.

United Nations. 2018. The Protection of Critical Infrastructure Against Terrorist Attacks: Compendium of Good Practices. Online available at https://www.un.org/sc/ctc/wpcontent/uploads/2018/06/Compendium-CIP-final-version120618_new_fonts_18_june_2018_optimized.pdf. 
Figure 1: Press Coverage of Terrorism in France, 2014-16

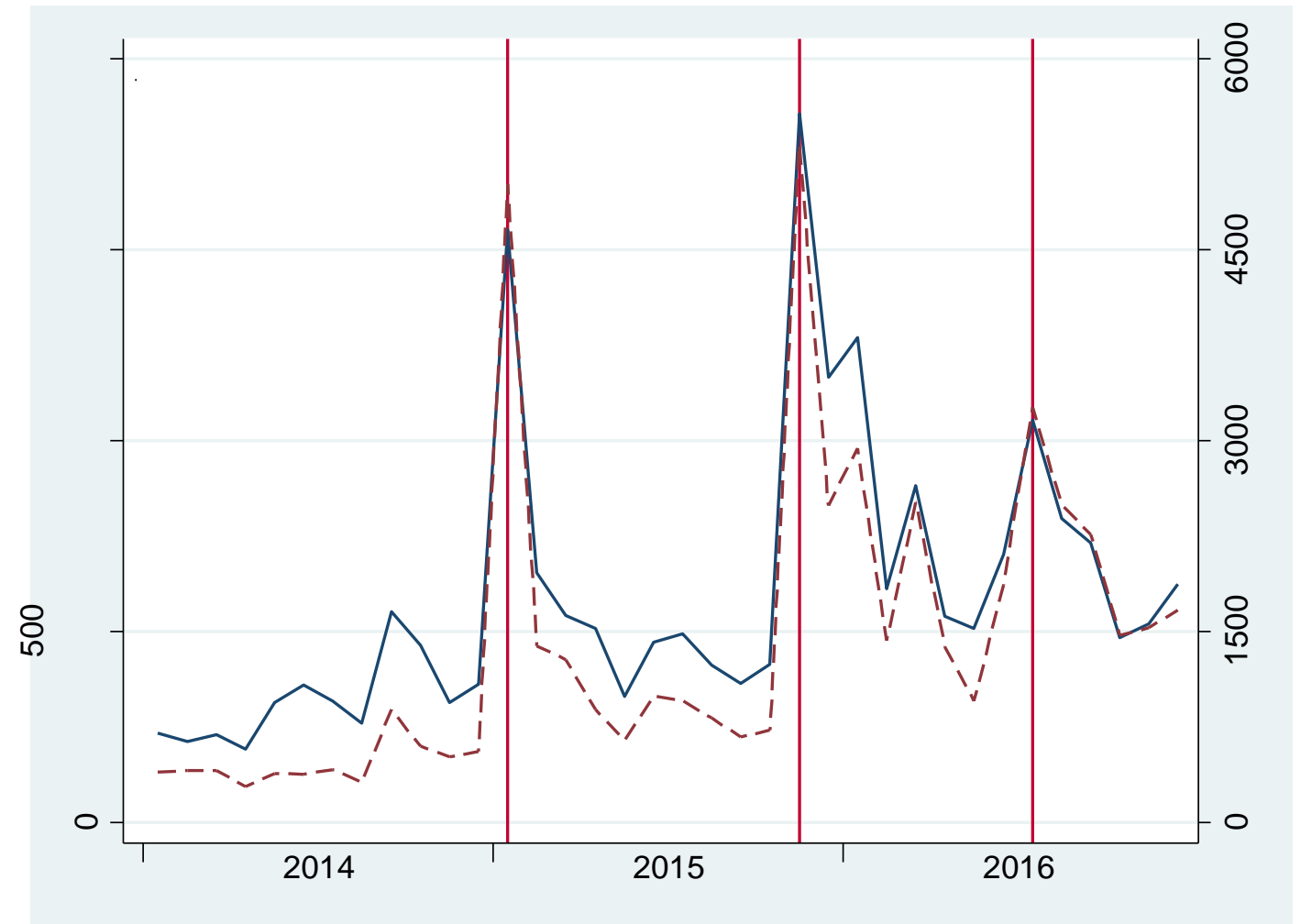

Notes: This graph plots the monthly number of occurrences of the words "Terrorisme" or "Terroriste" in national (solid line, left scale) and regional (dashed line, right scale) newspapers in France.

Source: Own compilation from Europresse database. 
Figure 2: Foreign Trade of France, 2014-16

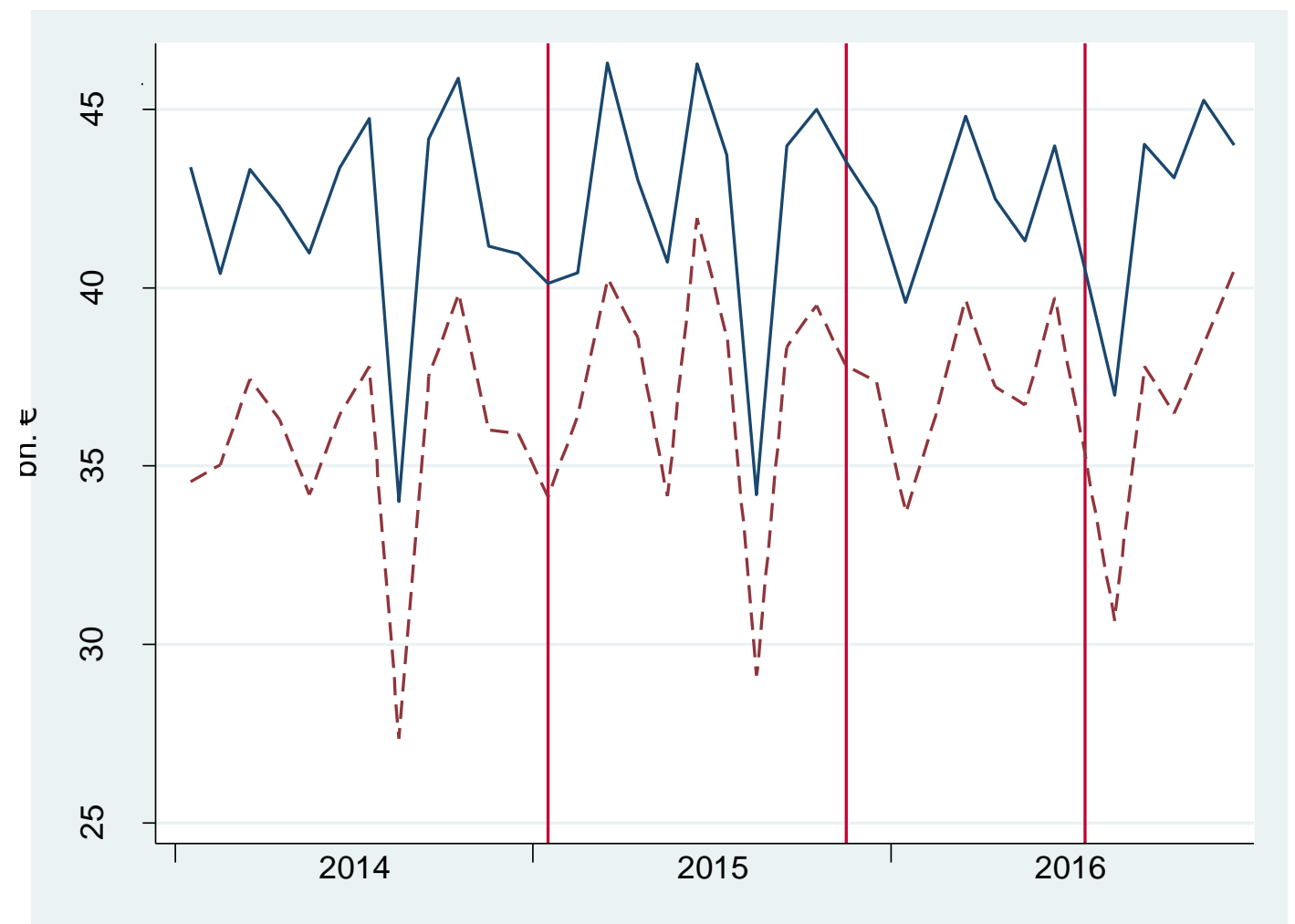

Notes: This graph plots monthly import values (solid line) and export values (dashed line) of France over the period from January 2014 to December 2016. The data are compiled from disaggregated French customs data (at country-firm-product level) which are used in our empirical analyses. Virtually identical monthly trade values are obtained from the national statistics institute of France, INSEE.

Source: Own compilation from French customs data (douane-française). 
Figure 3: The Effect of Terrorism on Trade over Time

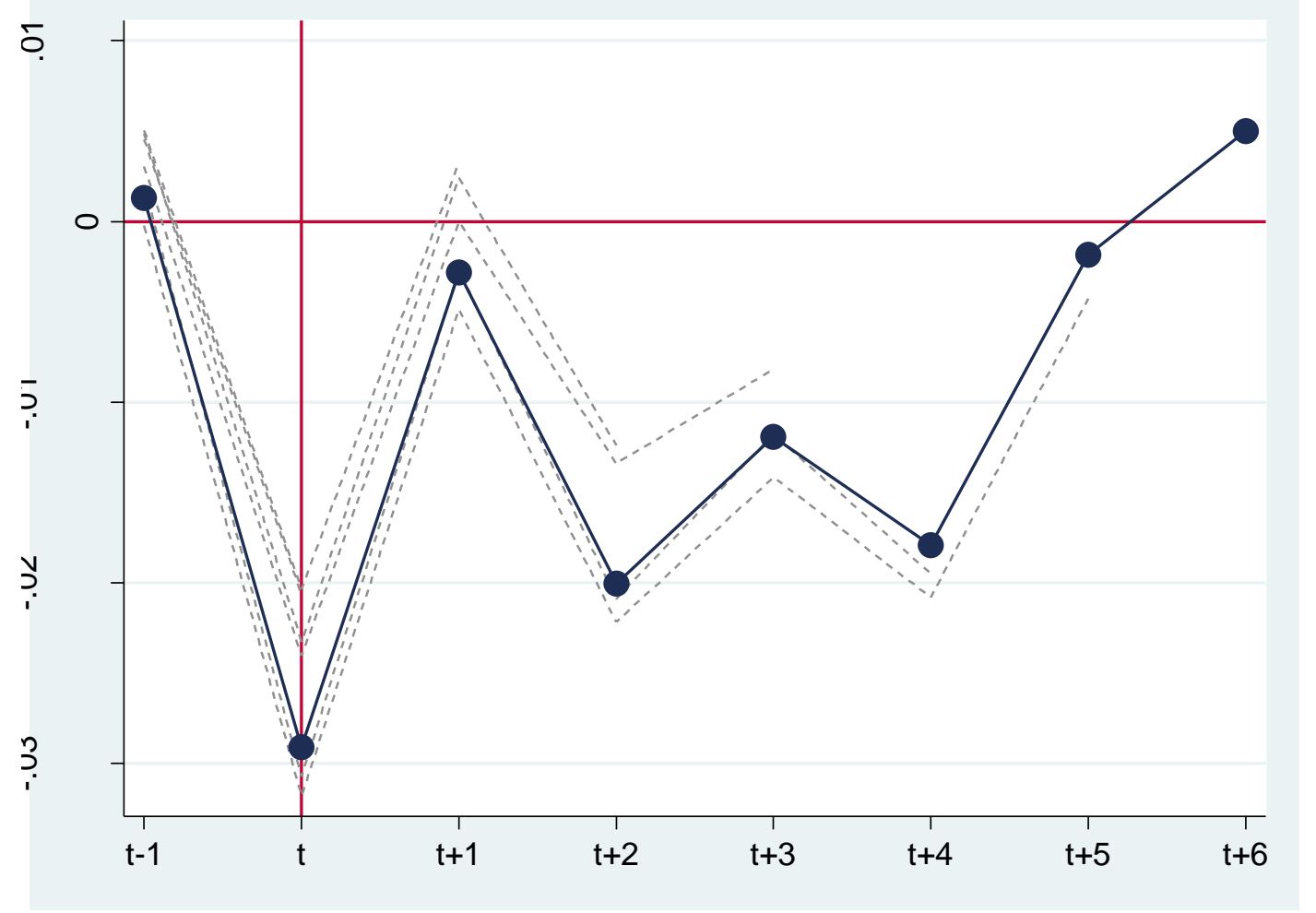

Notes: This graph plots estimated coefficients obtained from equation (2) when the time window which is analyzed is gradually expanded. Dotted lines show the estimated trade effects for time windows shorter than six months; the solid line with circles shows the estimation results from a regression which covers the period of six months after the month of the attack. 
Figure 4: The Aggregate Effect of Terrorism on Trade over Time

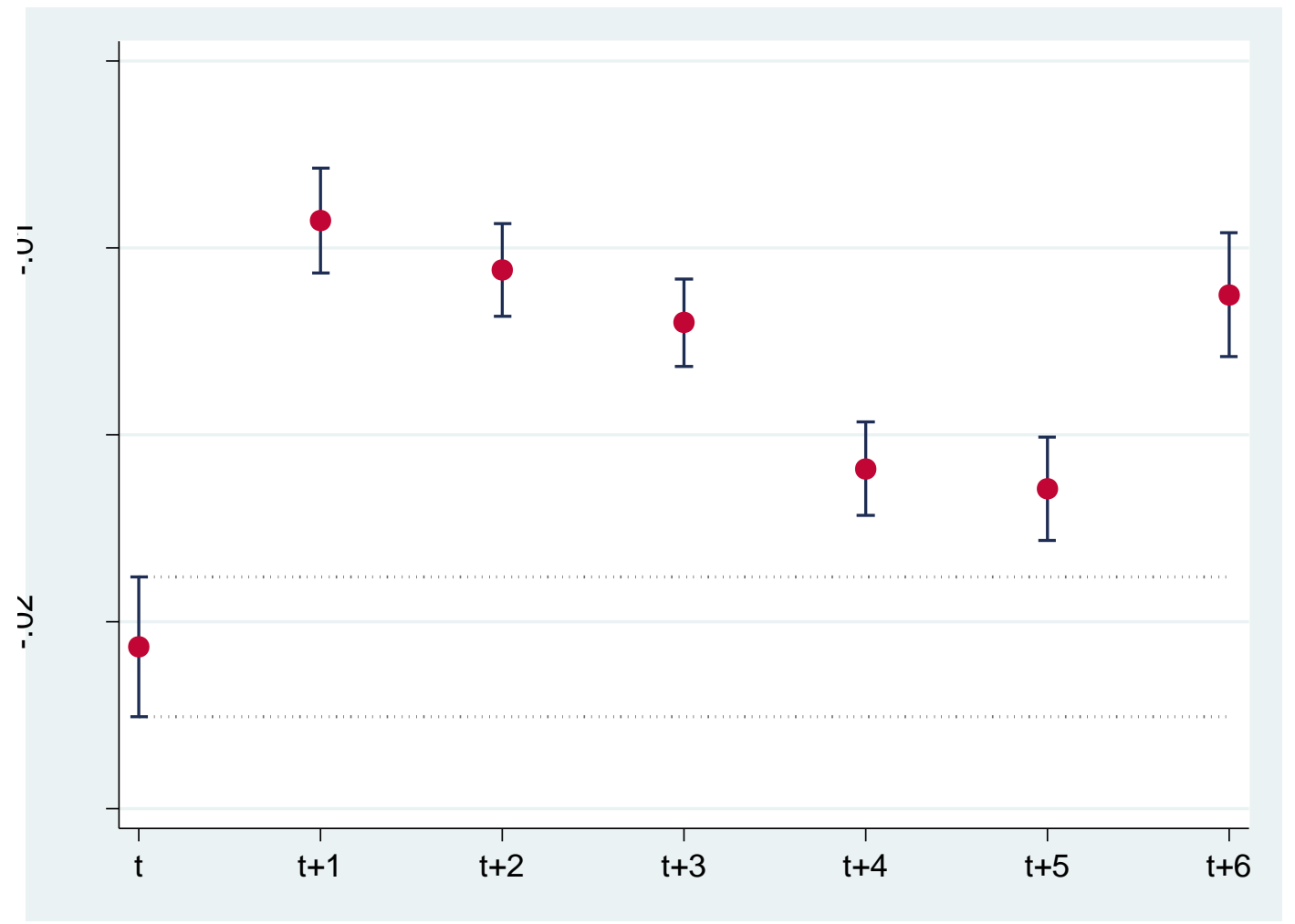

Notes: This graph plots estimated coefficients (and the 95\% confidence intervals) obtained from equation (3). Each dot represents the estimated (cumulative) trade effect of the attacks for the time window shown on the $\mathrm{x}$-axis. 
Figure 5: The Aggregate Effect of Terrorism on Trade by Individual Attack

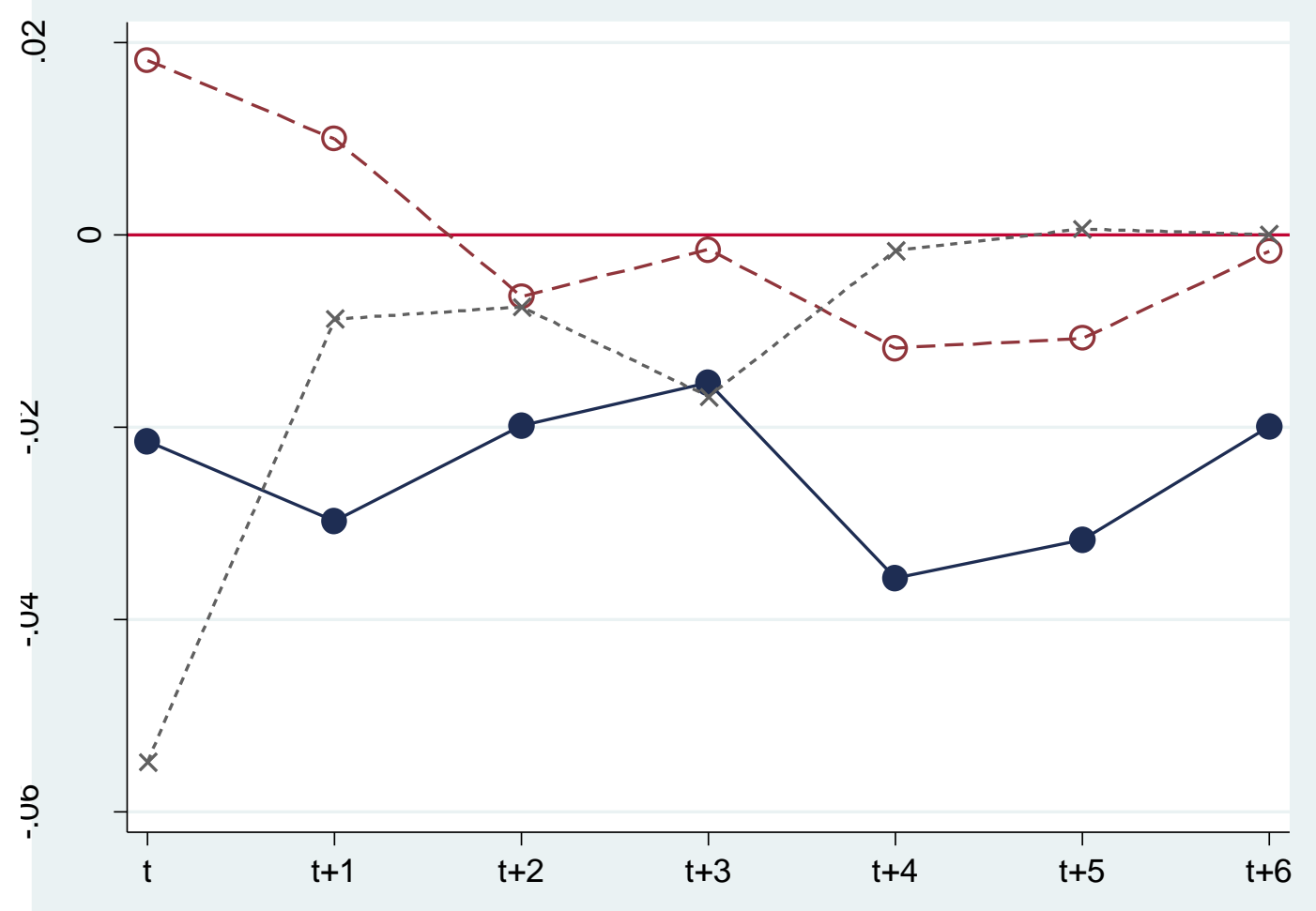

Notes: This graph plots estimated coefficients obtained from equation (1) by individual terrorist incident. The solid, dashed and dotted lines plot the effects of the attacks in January 2015, November 2015, and July 2016, respectively. 
Table 1: Terrorist Incidents in France, 2014-2016

\begin{tabular}{|c|c|c|c|c|}
\hline Date & Location & Deaths & Injuries & Incident \\
\hline 7 January 2015 & Paris & 12 & 11 & Charlie Hebdo shooting \\
\hline 8-9 January 2015 & Paris & 5 & 9 & $\begin{array}{l}\text { Hypercacher kosher } \\
\text { supermarket siege }\end{array}$ \\
\hline 19 April 2015 & Paris & 1 & 0 & Plot to attack churches \\
\hline 26 June 2015 & $\begin{array}{l}\text { Saint-Quentin- } \\
\text { Fallavier (Isère) }\end{array}$ & 1 & 2 & Air Products gas plant attack \\
\hline 21 August 2015 & Oignies & 0 & 5 & Thalys train attack \\
\hline $\begin{array}{l}13 \text { November } \\
2015\end{array}$ & Paris, Saint-Denis & 130 & $>400$ & $\begin{array}{l}\text { Bataclan theater shooting, } \\
\text { Stade de France bombing }\end{array}$ \\
\hline 13 June 2016 & $\begin{array}{l}\text { Magnanville } \\
\text { (Yvelines) }\end{array}$ & 2 & 0 & Police officer stabbing \\
\hline 14 July 2016 & $\begin{array}{l}\text { Nice (Alpes } \\
\text { Maritimes) }\end{array}$ & 86 & $>450$ & $\begin{array}{c}\text { Promenade des Anglais } \\
\text { truck-ramming attack }\end{array}$ \\
\hline 26 July 2016 & $\begin{array}{l}\text { Saint-Étienne-du- } \\
\text { Rouvray (Seine- } \\
\text { Maritime) }\end{array}$ & 1 & 0 & Church attack \\
\hline
\end{tabular}

Source: Le Monde, internet edition, March 23, 2018 
Table 2: Foreign Trade of France, 2014-2016

\begin{tabular}{|c|c|c|c|c|c|c|c|c|c|c|}
\hline \multirow[b]{2}{*}{ Year } & \multicolumn{5}{|c|}{ Imports } & \multicolumn{5}{|c|}{ Exports } \\
\hline & $\begin{array}{c}\text { Value } \\
\text { (bn. } € \text { ) }\end{array}$ & Entries & Countries & Firms & $\begin{array}{l}\text { Products } \\
\text { (CN8) }\end{array}$ & $\begin{array}{c}\text { Value } \\
\text { (bn. €) }\end{array}$ & Entries & Countries & Firms & $\begin{array}{l}\text { Products } \\
\text { (CN8) }\end{array}$ \\
\hline 2014 & 504.5 & $13,577,488$ & 247 & 128,839 & 9,240 & 428.4 & $10,429,978$ & 235 & 99,280 & 9,110 \\
\hline 2015 & 509.4 & $14,204,643$ & 245 & 130,497 & 9,227 & 446.3 & $10,813,786$ & 234 & 102,037 & 9,062 \\
\hline 2016 & 508.1 & $14,851,373$ & 245 & 134,988 & 9,278 & 442.6 & $11,157,682$ & 236 & 100,665 & 9,132 \\
\hline
\end{tabular}

Source: Own compilation from French customs data (douane-française). 
Table 3: The Effect of Terrorism on Trade at Disaggregate Level

\begin{tabular}{|l|c|c|c|c|c|c|}
\hline Direction of Trade & \multicolumn{5}{|c|}{ Imports } & Exports \\
\hline Dependent Variable & Log Value & Log Weight & Log Quantity & Log Unit Value & Log Value & Log Value \\
\hline Period & $2014-16$ & $2014-16$ & $2014-16$ & $2014-16$ & $2013-16$ & $2014-16$ \\
\hline Terrorist Incidents & $-0.0207^{* *}$ & $-0.0162^{* *}$ & $-0.0131^{* *}$ & $-0.0052^{* *}$ & $-0.0234^{* *}$ & $-0.0253^{* *}$ \\
& $(0.0009)$ & $(0.0009)$ & $(0.0021)$ & $(0.0005)$ & $(0.0009)$ & $(0.0010)$ \\
\hline Observations & $39,667,922$ & $37,792,038$ & $10,434,022$ & $38,430,5024$ & $51,930,722$ & $30,135,956$ \\
\hline Adj. $\mathbf{R}^{\mathbf{2}}$ & 0.76 & 0.84 & 0.75 & 0.85 & 0.76 & 0.80 \\
\hline
\end{tabular}

Notes: OLS estimation. The dependent variable is specified at the top of each column. The unit of observation is a (non-zero) country-firm-product triplet in monthly frequency. Months with major terrorist incidents are January 2015, November 2015, and July 2016. Country-firm-product fixed effects, year fixed effects and calendar month-specific fixed effects are included but not reported. Robust standard errors are in parentheses. ** denote significant at the $1 \%$ level. 
Table 4: Alternative Regression Specifications

\begin{tabular}{|c|c|c|c|c|c|c|c|}
\hline $\begin{array}{l}\text { Calendar Month-Fixed } \\
\text { Effects }\end{array}$ & $\begin{array}{l}\text { Country- } \\
\text { Month }\end{array}$ & $\begin{array}{l}\text { Firm- } \\
\text { Month }\end{array}$ & $\begin{array}{l}\text { Product- } \\
\text { Month }\end{array}$ & $\begin{array}{c}\text { Country- } \\
\text { Firm- } \\
\text { Month }\end{array}$ & $\begin{array}{c}\text { Country- } \\
\text { Product- } \\
\text { Month }\end{array}$ & $\begin{array}{l}\text { Firm- } \\
\text { Product- } \\
\text { Month }\end{array}$ & $\begin{array}{l}\text { Country- } \\
\text { Firm- } \\
\text { Product- } \\
\text { Month }\end{array}$ \\
\hline Terrorist Incidents & $\begin{array}{l}-0.0209 * * \\
(0.0009)\end{array}$ & $\begin{array}{l}-0.0204 * * \\
(0.0010)\end{array}$ & $\begin{array}{l}-0.0209 * * \\
(0.0009) \\
\end{array}$ & $\begin{array}{l}-0.0211^{* *} \\
(0.0010)\end{array}$ & $\begin{array}{l}-0.0212 * * \\
(0.0010)\end{array}$ & $\begin{array}{l}-0.0203 * * \\
(0.0011) \\
\end{array}$ & $\begin{array}{l}-0.0152 * * \\
(0.0010)\end{array}$ \\
\hline $\begin{array}{l}\text { Calendar Month FEs } \\
\text { Categories }\end{array}$ & 2,740 & 737,019 & 106,341 & $2,617,848$ & $1,464,508$ & $7,167,777$ & $9,298,040$ \\
\hline Observations & $39,667,824$ & $39,465,972$ & $39,665,112$ & $38,451,525$ & $39,179,448$ & $33,629,274$ & $31,388,402$ \\
\hline Adj. $R^{2}$ & 0.76 & 0.77 & 0.77 & 0.77 & 0.76 & 0.75 & 0.75 \\
\hline
\end{tabular}

Notes: OLS estimation. The dependent variable is the log value of imports. The unit of observation is a (non-zero) country-firm-product triplet in monthly frequency. The sample period is from 2014 to 2016. Months with major terrorist incidents are January 2015, November 2015, and July 2016. The type of calendar month-specific fixed effects is specified at the top of each column. Country-firm-product fixed effects and year fixed effects are included but not reported. Robust standard errors are in parentheses. ** denote significant at the $1 \%$ level. 
Table 5: The Effect of Terrorism on Trade at Aggregate Levels

\begin{tabular}{|l|c|c|c|c|c|}
\hline Level of Aggregation & $\begin{array}{c}\text { Country- } \\
\text { Product }\end{array}$ & Firm & Product & Country & $\begin{array}{c}\text { Country- } \\
\text { Product }\end{array}$ \\
\hline Period & $2014-16$ & $2014-16$ & $2014-16$ & $2014-16$ & $2013-16$ \\
\hline Terrorist Incidents & $-0.0064^{* *}$ & $-0.0246^{* *}$ & $-0.0412^{*}$ & $-0.1670 \#$ & $-0.0089^{* *}$ \\
& $(0.0006)$ & $(0.0055)$ & $(0.0164)$ & $(0.1013)$ & No \\
\hline Country-Product FEs & Yes & No & No & No & Yes \\
\hline Firm FEs & No & Yes & No & No & No \\
\hline Product FEs & No & No & Yes & Yes & No \\
\hline Country FEs & No & No & No & 8,892 & $112,086,624$ \\
\hline Observations & $84,064,968$ & $7,991,676$ & 340,344 & 0.86 & 0.82 \\
\hline Adj. $\mathbf{R}^{2}$ & 0.83 & 0.74 & 0.81 & & 0.86 \\
\hline
\end{tabular}

Notes: OLS estimation. The dependent variable is the log value of imports. Samples are balanced (including observations of zero trade) at the level of aggregation specified at the top of each column. Data are in monthly frequency. Year fixed effects and calendar month-specific fixed effects are included but not reported. Robust standard errors are in parentheses. **, * and \# denote significant at the 1\%, 5\% and $10 \%$ level, respectively. 
Table 6: Alternative Estimation Approaches

\begin{tabular}{|l|c|c|c|c|c|}
\hline Estimation Method & \multicolumn{3}{|c|}{ OLS with Clustering } & \multicolumn{2}{c|}{ Poisson } \\
\hline Dependent Variable & Log Value & Log Value & Log Value & Value & Value \\
\hline Period & $2014-16$ & $2014-16$ & $2014-16$ & $2014-16$ & $2014-16$ \\
\hline Level of Aggregation & $\begin{array}{c}\text { Country-Firm- } \\
\text { Product }\end{array}$ & $\begin{array}{c}\text { Country-Firm- } \\
\text { Product }\end{array}$ & $\begin{array}{c}\text { Country-Firm- } \\
\text { Product }\end{array}$ & $\begin{array}{c}\text { Country-Firm- } \\
\text { Product }\end{array}$ & Country-Product \\
\hline Terrorist Incidents & $-0.0207^{* *}$ & $-0.0207^{* *}$ & $-0.0207^{* *}$ & $-0.0391^{* *}$ & $-0.0219^{* *}$ \\
& $(0.0012)$ & $(0.0030)$ & $(0.0010)$ & $(0.0130)$ & $(0.0009)$ \\
\hline Clustering & Country & Firm & Product & - & - \\
\hline Observations & $39,667,922$ & $39,667,922$ & $39,667,922$ & $38,818,774$ & $84,064,968$ \\
\hline Adj. $\mathbf{R}^{2}$ & 0.76 & 0.76 & 0.75 & & \\
\hline
\end{tabular}

Notes: The first three columns use the same baseline specification as in the first column of Table 3, but compute robust standard errors (in parentheses) which are clustered as noted. The final two columns apply Poisson estimation at different levels of trade aggregation. Country-firmproduct fixed effects (except for the last column which includes country-product fixed effects), year fixed effects and calendar month-specific fixed effects are included but not reported. $* *$ denote significant at the $1 \%$ level. 
Table 7: The Effect of Terrorism on Trade over Time

\begin{tabular}{|l|c|c|c|c|c|c|}
\hline Direction of Trade & \multicolumn{5}{|c|}{ Imports } & Exports \\
\hline Dependent Variable & Log Value & Log Weight & Log Quantity & Log Unit Value & Log Value & Log Value \\
\hline Period & $2014-16$ & $2014-16$ & $2014-16$ & $2014-16$ & $2013-16$ & $2014-16$ \\
\hline 1 Month Before & 0.0013 & 0.0010 & 0.0029 & -0.0009 & $0.0064^{* *}$ & $0.0054^{* *}$ \\
& $(0.0013)$ & $(0.0012)$ & $(0.0028)$ & $(0.0007)$ & $(0.0011)$ & $(0.0014)$ \\
\hline Terrorist Incidents & $-0.0291^{* *}$ & $-0.0210^{* *}$ & $-0.0243^{* *}$ & $-0.0094^{* *}$ & $-0.0313^{* *}$ & $-0.0169^{* *}$ \\
& $(0.0014)$ & $(0.0014)$ & $(0.0030)$ & $(0.0007)$ & $(0.0013)$ & $(0.0015)$ \\
\hline 1 Month After & $-0.0028^{*}$ & -0.0003 & $0.0060^{*}$ & $-0.0030^{* *}$ & 0.0003 & $0.0226^{* *}$ \\
& $(0.0014)$ & $(0.0014)$ & $(0.0030)$ & $(0.0008)$ & $(0.0013)$ & $(0.0015)$ \\
\hline 2 Months After & $-0.0200^{* *}$ & $-0.0156^{* *}$ & $-0.0317^{* *}$ & $-0.0060^{* *}$ & $-0.0195^{* *}$ & $-0.0065^{* *}$ \\
& $(0.0013)$ & $(0.0013)$ & $(0.0029)$ & $(0.0007)$ & $(0.0012)$ & $(0.0014)$ \\
\hline 3 Months After & $-0.0119^{* *}$ & $-0.0105^{* *}$ & $-0.0147^{* *}$ & $-0.0027^{* *}$ & $-0.0157^{* *}$ & $0.0040^{* *}$ \\
& $(0.0014)$ & $(0.0014)$ & $(0.0032)$ & $(0.0008)$ & $(0.0013)$ & $(0.0015)$ \\
\hline 4 Months After & $-0.0179^{* *}$ & $-0.0147^{* *}$ & $-0.0235^{* *}$ & $-0.0043^{* *}$ & $-0.0153^{* *}$ & $0.0039^{*}$ \\
& $(0.0014)$ & $(0.0014)$ & $(0.0032)$ & $(0.0008)$ & $(0.0013)$ \\
\hline 5 Months After & -0.0018 & 0.0016 & $-0.0094^{*}$ & $-0.0043^{* *}$ & 0.0010 \\
& $(0.0015)$ & $(0.0015)$ & $(0.0034)$ & $(0.0008)$ & $(0.0014)$ \\
\hline 6 Months After & $0.0050^{* *}$ & $0.0112^{* *}$ & $0.0082^{*}$ & $-0.0054^{* *}$ & -0.0010 \\
& $(0.0015)$ & $(0.0015)$ & $(0.0034)$ & $(0.0008)$ & $(0.0014)$ \\
\hline Observations & $39,667,922$ & $37,792,038$ & $10,434,022$ & $38,430,502$ & $51,930,722$ & $30.0016)$ \\
\hline Adj. R ${ }^{2}$ & 0.76 & 0.84 & 0.75 & 0.85 & $0.0258^{* *}$ \\
\hline
\end{tabular}

Notes: OLS estimation. The dependent variable is specified at the top of each column. The unit of observation is a (non-zero) country-firm-product triplet in monthly frequency. Months with major terrorist incidents are January 2015, November 2015, and July 2016. Country-firm-product fixed effects, year fixed effects and calendar month-specific fixed effects are included but not reported. Robust standard errors are in parentheses. **,* and \# denote significant at the $1 \%, 5 \%$ and $10 \%$ level, respectively. 
Table 8: The Effect of Terrorism on Trade along Extensive and Intensive Margins

\begin{tabular}{|l|l|l|c|c|}
\hline Direction of Trade & \multicolumn{2}{|c|}{ Imports } & \multicolumn{2}{c|}{ Exports } \\
\hline Period & $2014-16$ & $2013-16$ & $2014-16$ & $2013-16$ \\
\hline Value & -0.0457 & $-0.0489 \#$ & $-0.0444 \#$ & $-0.0481 \#$ \\
& $(0.0283)$ & $(0.0280)$ & $(0.0224)$ & $(0.0245)$ \\
\hline Countries & -0.0043 & -0.0039 & $0.0148 \#$ & 0.0103 \\
& $(0.0068)$ & $(0.0060)$ & $(0.0075)$ & $(0.0060)$ \\
\hline Firms & -0.0045 & -0.0070 & -0.0151 & -0.0169 \\
& $(0.0064)$ & $(0.0066)$ & $(0.0108)$ & $(0.0112)$ \\
\hline Products & 0.0004 & -0.0004 & 0.0007 & 0.0004 \\
& $(0.0012)$ & $(0.0013)$ & $(0.0018)$ & $(0.0022)$ \\
\hline Density & -0.0120 & -0.0209 & $-0.0483^{*}$ & $-0.0492^{*}$ \\
& $(0.0148)$ & $(0.0162)$ & $(0.0224)$ & $(0.0237)$ \\
\hline Intensive & $-0.0335 \#$ & $-0.0315 \#$ & $-0.0253^{*}$ & $-0.0257^{*}$ \\
& $(0.0168)$ & $(0.0168)$ & $(0.0094)$ & $(0.0117)$ \\
\hline Observations & 36 & 48 & 36 & 48 \\
\hline
\end{tabular}

Notes: OLS estimation. Each cell contains the results of a separate regression. The dependent variable is the margin of trade (in logs), specified in the first column of each row, in monthly frequency. Months with major terrorist incidents are January 2015, November 2015, and July 2016. Year fixed effects and calendar month-specific fixed effects are included but not reported. Robust standard errors are in parentheses. **,* and \# denote significant at the $1 \%$, $5 \%$ and $10 \%$ level, respectively. 
Table 9: The Effect of Terrorism on Trade by Country

\begin{tabular}{|c|c|c|c|c|c|c|c|c|c|c|c|c|}
\hline \multirow[b]{2}{*}{ Terrorist Incidents } & \multicolumn{6}{|c|}{$\begin{array}{c}\text { Immediate Effect } \\
\text { (in the Month of the Attack) }\end{array}$} & \multicolumn{6}{|c|}{$\begin{array}{c}\text { Aggregate Effect } \\
\text { (Over the Period of } 6 \text { Months After the Attack) }\end{array}$} \\
\hline & $\begin{array}{l}-0.0207 * * \\
(0.0009) \\
\end{array}$ & $\begin{array}{l}-0.0177 * * \\
(0.0012) \\
\end{array}$ & $\begin{array}{l}-0.0135 * * \\
(0.0014) \\
\end{array}$ & $\begin{array}{c}-0.0138^{* *} \\
(0.0014) \\
\end{array}$ & $\begin{array}{l}-0.0205^{* *} \\
(0.0009) \\
\end{array}$ & $\begin{array}{l}-0.0127 * * \\
(0.0014) \\
\end{array}$ & $\begin{array}{l}-0.0113 * * \\
(0.0008) \\
\end{array}$ & $\begin{array}{l}-0.0081 * * \\
(0.0009)\end{array}$ & $\begin{array}{l}-0.0066^{* *} \\
(0.0010) \\
\end{array}$ & $\begin{array}{l}-0.0054 * * \\
(0.0011) \\
\end{array}$ & $\begin{array}{l}-0.0110 * * \\
(0.0008) \\
\end{array}$ & $\begin{array}{l}-0.0047 * * \\
(0.0011) \\
\end{array}$ \\
\hline $\begin{array}{l}\text { Terrorist Incidents } \times \\
\text { French Overseas } \\
\text { Territories }\end{array}$ & $\begin{array}{l}-0.0298 \\
(0.0607)\end{array}$ & & & & & $\begin{array}{l}-0.0378 \\
(0.0607)\end{array}$ & $\begin{array}{c}0.0565 \\
(0.0386)\end{array}$ & & & & & $\begin{array}{c}0.0499 \\
(0.0386)\end{array}$ \\
\hline $\begin{array}{l}\text { Terrorist Incidents } \times \\
\text { Border Countries }\end{array}$ & & $\begin{array}{l}-0.0075^{* *} \\
(0.0015)\end{array}$ & & & & $\begin{array}{l}0.0070^{* *} \\
(0.0021)\end{array}$ & & $\begin{array}{l}-0.0078^{* *} \\
(0.0009) \\
\end{array}$ & & & & $\begin{array}{l}-0.0027^{*} \\
(0.0013) \\
\end{array}$ \\
\hline $\begin{array}{l}\text { Terrorist Incidents } \times \\
\text { Schengen Countries }\end{array}$ & & & $\begin{array}{l}-0.0135^{* *} \\
(0.0015)\end{array}$ & & & $\begin{array}{l}-0.0173 * * \\
(0.0032)\end{array}$ & & & $\begin{array}{l}-0.0088^{* *} \\
(0.0009)\end{array}$ & & & $\begin{array}{c}0.0014 \\
(0.0019) \\
\end{array}$ \\
\hline $\begin{array}{l}\text { Terrorist Incidents } \times \\
\text { EU Countries }\end{array}$ & & & & $\begin{array}{c}-0.0121 * * \\
(0.0016) \\
\end{array}$ & & $\begin{array}{l}-0.0023 \\
(0.0028) \\
\end{array}$ & & & & $\begin{array}{l}-0.0103 * * \\
(0.0010) \\
\end{array}$ & & $\begin{array}{l}-0.0104 * * \\
(0.0017) \\
\end{array}$ \\
\hline $\begin{array}{l}\text { Terrorist Incidents } \times \\
\text { Home Countries of } \\
\text { Attackers' Parents }\end{array}$ & & & & & $\begin{array}{l}-0.0157 \# \\
(0.0091)\end{array}$ & $\begin{array}{l}-0.0236^{*} \\
(0.0092)\end{array}$ & & & & & $\begin{array}{l}-0.0195 * * \\
(0.0055)\end{array}$ & $\begin{array}{l}-0.0258 * * \\
(0.0055)\end{array}$ \\
\hline Observations & $39,667,922$ & $39,667,922$ & $39,667,922$ & $39,667,922$ & $39,667,922$ & $39,667,922$ & $39,667,922$ & $39,667,922$ & $39,667,922$ & $39,667,922$ & $39,667,922$ & $39,667,922$ \\
\hline Adj. $\mathbf{R}^{2}$ & 0.76 & 0.76 & 0.76 & 0.76 & 0.76 & 0.76 & 0.76 & 0.76 & 0.76 & 0.76 & 0.76 & 0.76 \\
\hline
\end{tabular}

Notes: OLS estimation. The dependent variable is the log value of imports. The unit of observation is a (non-zero) country-firm-product triplet in monthly frequency. The sample period is from 2014 to 2016. Months with major terrorist incidents are January 2015, November 2015, and July 2016. Country-firm-product fixed effects, year fixed effects and calendar month-specific fixed effects are included but not reported. Robust standard errors are in parentheses. ${ }^{* *}, *$ and $\#$ denote significant at the $1 \%, 5 \%$ and $10 \%$ level, respectively. 
Table 10: The Effect of Terrorism on Trade by Firm

\begin{tabular}{|c|c|c|c|c|c|c|}
\hline \multirow[b]{2}{*}{ Terrorist Incidents } & \multicolumn{3}{|c|}{$\begin{array}{l}\text { Immediate Effect } \\
\text { (in the Month of the Attack) }\end{array}$} & \multicolumn{3}{|c|}{$\begin{array}{c}\text { Aggregate Effect } \\
\text { (Over the Period of } 6 \text { Months After the Attack) }\end{array}$} \\
\hline & $\begin{array}{l}-0.0309 * * \\
(0.0018)\end{array}$ & $\begin{array}{l}-0.0201 * * \\
(0.0011)\end{array}$ & $\begin{array}{l}-0.0192 * * \\
(0.0011)\end{array}$ & $\begin{array}{l}-0.0329 * * \\
(0.0013)\end{array}$ & $\begin{array}{l}-0.0075^{* *} \\
(0.0009)\end{array}$ & $\begin{array}{l}-0.0114 * * \\
(0.0009)\end{array}$ \\
\hline $\begin{array}{l}\text { Terrorist Incidents } \times \\
\text { Large Firm }\end{array}$ & $\begin{array}{l}0.0119^{* *} \\
(0.0020)\end{array}$ & & & $\begin{array}{l}0.0253^{* *} \\
(0.0012)\end{array}$ & & \\
\hline $\begin{array}{l}\text { Terrorist Incidents } \times \\
\text { Firm Located in Region } \\
\text { of Terrorist Incident }\end{array}$ & & $\begin{array}{l}-0.0013 \\
(0.0020)\end{array}$ & & & $\begin{array}{l}-0.0203 * * \\
(0.0012)\end{array}$ & \\
\hline $\begin{array}{l}\text { Terrorist Incidents } \times \\
\text { Firm Located in Border } \\
\text { Region }\end{array}$ & & & $\begin{array}{l}-0.0053 * * \\
(0.0020)\end{array}$ & & & $\begin{array}{l}-0.0027 * \\
(0.0012)\end{array}$ \\
\hline Observations & $39,667,922$ & $35,375,343$ & $35,375,343$ & $39,667,922$ & $35,375,343$ & $35,375,343$ \\
\hline Adj. $R^{2}$ & 0.76 & 0.76 & 0.76 & 0.76 & 0.76 & 0.76 \\
\hline
\end{tabular}

Notes: OLS estimation. The dependent variable is the log value of imports. The unit of observation is a (non-zero) country-firm-product triplet in monthly frequency. The sample period is from 2014 to 2016. Months with major terrorist incidents are January 2015, November 2015, and July 2016. A firm is classified as 'large' when it has reported imports in every month of the (36-months) sample period. According to this definition, there are 28,223 large firms ( 20\%) in our sample. Regions of incidents are the départements Paris (75), Hauts-de-Seine (92), Seine-St-Denis (93), Val-de-Marne (94), and Alpes Maritimes (06). Border regions are départements with a common land border with a neighboring country. Countryfirm-product fixed effects, year fixed effects and calendar month-specific fixed effects are included but not reported. Robust standard errors are in parentheses. **, * and \# denote significant at the $1 \%, 5 \%$ and $10 \%$ level, respectively. 
Table 11: The Effect of Terrorism on Trade by Product Category

\begin{tabular}{|c|c|c|c|c|c|c|c|c|c|c|}
\hline \multirow[b]{2}{*}{ Terrorist Incidents } & \multicolumn{5}{|c|}{$\begin{array}{l}\text { Immediate Effect } \\
\text { (in the Month of the Attack) }\end{array}$} & \multicolumn{5}{|c|}{$\begin{array}{c}\text { Aggregate Effect } \\
\text { (Over the Period of } 6 \text { Months After the Attack) }\end{array}$} \\
\hline & $\begin{array}{l}-0.0181 * * \\
(0.0010)\end{array}$ & $\begin{array}{l}-0.0201 * * \\
(0.0009)\end{array}$ & $\begin{array}{l}-0.0191 * * \\
(0.0010)\end{array}$ & $\begin{array}{l}-0.0305^{* *} \\
(0.0014)\end{array}$ & $\begin{array}{l}-0.0275^{* *} \\
(0.0021)\end{array}$ & $\begin{array}{l}-0.0121 * * \\
(0.0008)\end{array}$ & $\begin{array}{l}-0.0108 * * \\
(0.0008)\end{array}$ & $\begin{array}{l}-0.0121 * * \\
(0.0009)\end{array}$ & $\begin{array}{l}-0.0069 * * \\
(0.0010)\end{array}$ & $\begin{array}{l}-0.0047 * * \\
(0.0014)\end{array}$ \\
\hline $\begin{array}{l}\text { Terrorist Incidents } \times \\
\text { Fresh Food }\end{array}$ & $\begin{array}{l}-0.0515^{* *} \\
(0.0027)\end{array}$ & & & & & $\begin{array}{l}0.0172^{* *} \\
(0.0016)\end{array}$ & & & & \\
\hline $\begin{array}{l}\text { Terrorist Incidents } \times \\
\text { Organized Exchange }\end{array}$ & & $\begin{array}{l}-0.0269 * * \\
(0.0040)\end{array}$ & & & $\begin{array}{l}-0.0196 * * \\
(0.0044)\end{array}$ & & $\begin{array}{l}-0.0217 * * \\
(0.0024)\end{array}$ & & & $\begin{array}{l}-0.0278 * * \\
(0.0026)\end{array}$ \\
\hline $\begin{array}{l}\text { Terrorist Incidents } \times \\
\text { Reference Priced }\end{array}$ & & & $\begin{array}{l}-0.0122 * * \\
(0.0019)\end{array}$ & & $\begin{array}{l}-0.0038 \\
(0.0026)\end{array}$ & & & $\begin{array}{l}0.0065 * * \\
(0.0011)\end{array}$ & & $\begin{array}{l}-0.0008 \\
(0.0016)\end{array}$ \\
\hline $\begin{array}{l}\text { Terrorist Incidents } \times \\
\text { Differentiated } \\
\text { Products }\end{array}$ & & & & $\begin{array}{l}0.0139 * * \\
(0.0016)\end{array}$ & $\begin{array}{l}0.0110^{* *} \\
(0.0022)\end{array}$ & & & & $\begin{array}{l}-0.0062 * * \\
(0.0009)\end{array}$ & $\begin{array}{l}-0.0083 * * \\
(0.0013)\end{array}$ \\
\hline Observations & $39,667,922$ & $39,667,922$ & $39,667,922$ & $39,667,922$ & $39,667,922$ & $39,667,922$ & $39,667,922$ & $39,667,922$ & $39,667,922$ & $39,667,922$ \\
\hline Adj. $R^{2}$ & 0.76 & 0.76 & 0.76 & 0.76 & 0.76 & 0.76 & 0.76 & 0.76 & 0.76 & 0.76 \\
\hline
\end{tabular}

Notes: OLS estimation. The dependent variable is the log value of imports. The unit of observation is a (non-zero) country-firm-product triplet in monthly frequency. The sample period is from 2014 to 2016. Months with major terrorist incidents are January 2015, November 2015, and July 2016. 'Fresh food' comprises all product lines in the following (2-digits) chapters in the Combined Nomenclature: 2, 3, 4, 6, 7, 8, 9, 16. In the remaining four columns, products are categorized according to James Rauch's 'conservative' classification (https://econweb.ucsd.edu/ jrauch/rauch_classification.html). Country-firm-product fixed effects, year fixed effects and calendar month-specific fixed effects are included but not reported. Robust standard errors are in parentheses. **, * and \# denote significant at the $1 \%, 5 \%$ and $10 \%$ level, respectively. 